\title{
Waste of Copper Alloy Chips as Biogas Desulfurizer
}

\author{
Tjokorda Gde Tirta Nindhia, I. Wayan Surata, Tjokorda Sari Nindhia, Dewa Ngakan Ketut Putra Negara, \\ and Mega Diantoro
}

\begin{abstract}
The existence of hydrogen sulfide $\left(\mathrm{H}_{2} \mathrm{~S}\right)$ as impurities in the biogas resulting problematic for using biogas as a fuel since it will increase the acidity of the lubricant of the engine. Hydrogen sulfide is a corrosive gas that can corrodes the steel tank of biogas container. Other problem concerning $\mathrm{H}_{2} \mathrm{~S}$ is, this type of gas is a harmful gas that should be avoided. This work introduces a technique to utilize copper alloy chips waste that is obtained from manufacturing process. By galvanic coupling with iron chips in salt water the $\mathrm{Fe}^{2+}$ is released on the surface of iron chips and react with $\mathrm{H}_{2} \mathrm{~S}$ to produce $\mathrm{FeS}$. The iron chips that are used for this purpose also come from the iron chips waste. It is found the more addition of iron chips in to the mixture of copper chips the more reactive the desulfurizer.
\end{abstract}

Index Terms-Copper, galvanic, coupling, biogas, desulfurizerhidrofen sulfide.

\section{INTRODUCTION}

Hydrogen sulfide $\left(\mathrm{H}_{2} \mathrm{~S}\right)$ impurities in the biogas has to be removed before combusted to prevent toxicity, environmental problem caused by emission of sulfur (S) compound, and corrosion on equipment [1].

Some method for desulfurization that was established such method of sulfate-resistant Acidithiobacillysthiooxidans AZ11 [2]. This technique is not much attracting attention from the consumer because it was not easy to handle the bacteria.

Foam formation from the gas stream [1] was introduced in the early beginning method for the removal of $\mathrm{H}_{2}$ S.This technique was not attract the customer because the reason of simplicity, especially for the consumer from developing country.

Natural product such as zeolite can be used as desulfurizer [3]. Cost to delivery zeolite from mining location to the place of biogas installation could be a problem. Zeolite is a mining product with reasonable price but only available in certain region.

It was an interesting idea to utilizea waste for desulfurizer [4]. The waste that was used come from sewage sludge and

Manuscript received May 5, 2016; revised July 18, 2016. This work was supported financially by the Ministry R Higher Education The Republic of Indonesia through Scheme Science Technology for Society (Iptek Bagi Masyarakat/IbM) for the year 2016) under contract number 485.27/UN14.2/PKM.08.00/2016

Tjokorda Gde Tirta Nindhia, I. WayanSurata, Dewa Ngakan Ketut Putra Negara, and Mega Diantorowas are with the Department of Mechanical Engineering, Engineering Faculty, Udayana University Jimbaran, Bali, Indonesia (e-mail: nindhia@yahoo.com).

Tjokorda Sari Nindhia is with the Department of Veterinary Medicine University Denpasar, Bali, Indonesia. metal sludge of various compositions. But this technique becomes not appropriate from economic point of view because the sludge should be pyrolysed at quite high temperature. Other types of the waste that already used was fly ash for desulfurizer [5].Similarly, this technique become not popular since pyrolysis process at high temperature (around $900^{\circ} \mathrm{C}$ )is needed.

Wastes of metal chips recently are promoted as desulfurizer [6]. By utilizing steel chips waste, the regenerative type of desulfurizer can be developed. This type of desulfurizer can be use repetitively and already successful as a component for conversion of gasoline to biogas fueled single cylinder of four stroke engine of electric generator [7].

The metal waste from manufacturing industry are not only steel of iron but other type such as aluminium chips waste are much available because many component of the engine are made from aluminium. Aluminium is not reactive to $\mathrm{H}_{2} \mathrm{~S}$ even though in the form of aluminium oxide but can be used as desulfurizer [8] with galvanic coupling method [9].

The remaining of metal chips waste is copper alloy such as brass. It is the purpose of this research to use the waste of copper alloy chips as desulfurizer by using galvanic coupling method. Galvanic coupling is a potential difference that exists between two joined dissimilar metals immersed in electrolyte solution. The potential difference yield electron flow and metal ion will be released from one of the coupling [9]. The metal ion will react with $\mathrm{H}_{2} \mathrm{~S}$ in the biogas so that the process of desulfurization to occur.

\section{EXPERIMENTAL}

The waste of copper alloy chips was obtained from metal manufacturing process such as from milling and turning processes as depicted in Fig. 1. The protocol for the experimental followed our previous research [9] and the particle size was ignored.

The copper chips (Fig. 1) were mixed with iron chips in order galvanic coupling to occur. The iron chips were also obtained from waste of metal manufacturing industry as can be seen in Fig. 2. It was prepared 5 composition of mixtures (in wt. \%) Namely: $100 \% \mathrm{Cu}, 75 \% \mathrm{Cu}+25 \% \mathrm{Fe}, 50 \%$ $\mathrm{Cu}+50 \% \mathrm{Fe}, 25 \% \mathrm{Cu}+75 \% \mathrm{Fe}$ and $100 \% \mathrm{Fe}$.

The mixtures then are immersed inside salt-water solution (250 gram salt in 2 liters of water) for 48 hours so that galvanic corrosion to occur. After immersed for 48 hours in salt water the desulfurizer was taken out and installed as desulfurizer in the system of biogas pipe line. It should be noted that galvanic corrosion will not occur for the mixture of $100 \% \mathrm{Cu}$ and $100 \% \mathrm{Fe}$ since only single metal that exist but indeed oxidation occur and will yield copper oxide for copper alloy and iron oxide for iron 


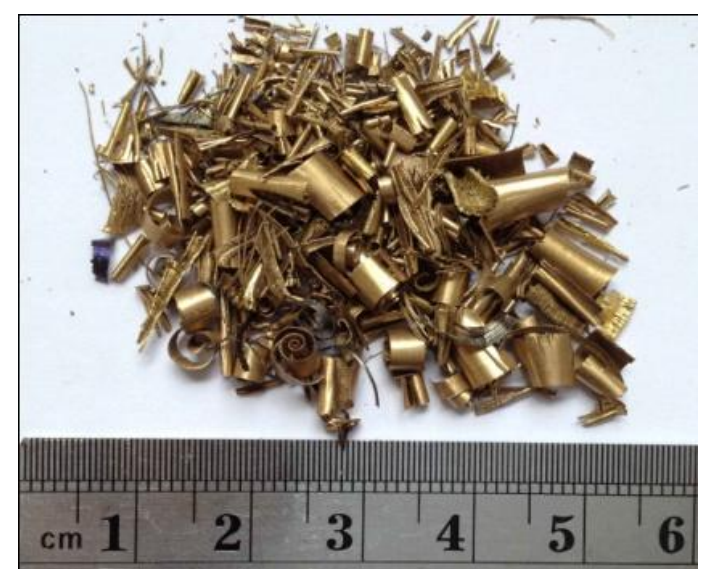

Fig. 1. Waste of copper alloy chips.

The performance of desulfurizer was evaluated by measuring the $\mathrm{H}_{2} \mathrm{~S}$ contents in the biogas before and after passing the desulfurizer as can be seen in Fig. 3. The performance of desulfurizer was measured for every 5 liters of biogas that passed the desulfurizer and was stopped until reach 50 liter.It was prepared around 500 gram of each mixture as desulfurizer and installed in the biogas pipe line system. The system was arranged with flow rate about 3 liters/minute.

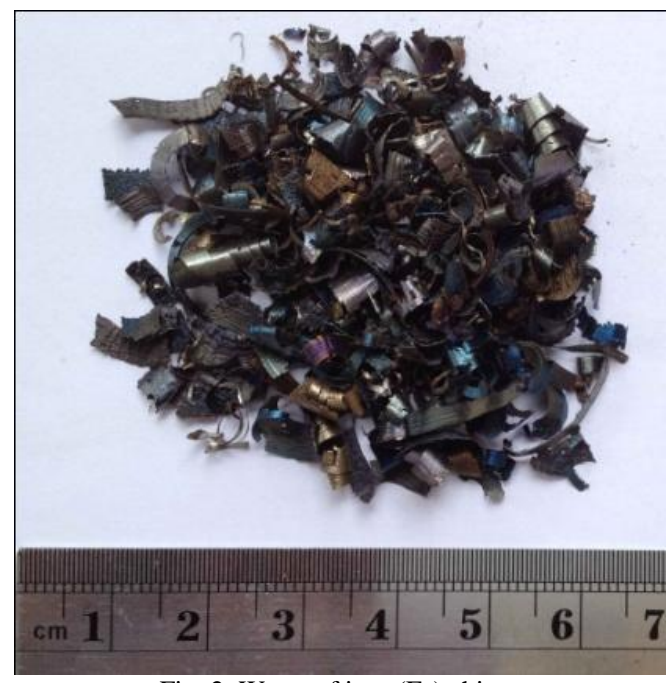

Fig. 2. Waste of iron (Fe) chips.

From gas container 1 the biogas was let flow and the flow rate was controlled by using valve 2 . The flow rate was controlled by using flow rate indicator 3 .

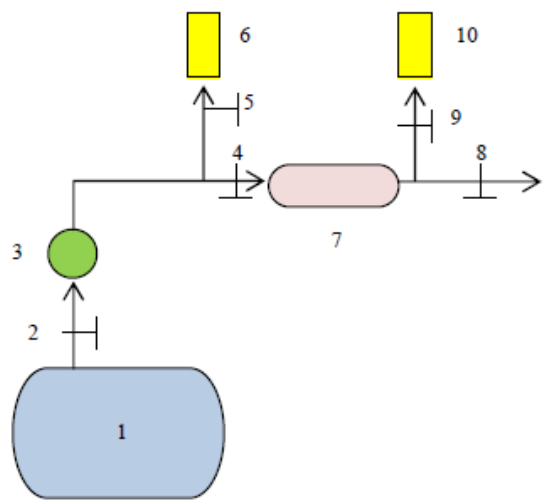

Fig. 3. Schematic of experiment for desulfurizer test performance: 1. Biogas container, 2.Valve, 3.Flow rate indicator, 4. Valve, 5. valve, $6 . \mathrm{H}_{2} \mathrm{~S}$ gas sensor, 7. Desulfurizer, 8. Valve, 9.valve, $10 . \mathrm{H}_{2} \mathrm{~S}$ gas sensor.
The position of valves during measurement of $\mathrm{H}_{2} \mathrm{~S}$ contents in the biogas before entering desulfurizer is: the valve 4 was closed and the valve 5 was opened and let the biogas flowed to the $\mathrm{H}_{2} \mathrm{~S}$ gas sensor 6 .

If the desulfurizer working properly, the $\mathrm{H}_{2} \mathrm{~S}$ contents in the biogas will decrease and can be measured by closing valve 8 and then open the valve 9 and let the biogas to $\mathrm{H}_{2} \mathrm{~S}$ gas sensor 10.The performance of desulfurizer then can be calculated by using Eq. 1. The result then will be presented in graft and analyzed.

$$
\frac{\mathrm{H}_{2} \text { Sbeforedesulfurizer }-\mathrm{H}_{2} \text { Safterdesulfurizer }}{\mathrm{H}_{2} \text { Sbeforedesulfurizer }} \times 100 \%
$$

\section{RESUlT AND DisCUSSION}

It is found that the performance of desulfurizer by using $100 \%$ of copper alloy chips is almost zero which ismeansthat if copper is put in salt water will produce copper oxide which is not reactive to $\mathrm{H}_{2} \mathrm{~S}$ and cannot act as desulfurizer (the result is presented in the Fig. 4). When small amount of iron chips is added $(75 \% \mathrm{Cu}+25 \% \mathrm{Fe})$, the performance increase significantly which is around 40-90\% in reducing amount of $\mathrm{H}_{2} \mathrm{~S}$. This is a positive indication for application as desulfurizer.

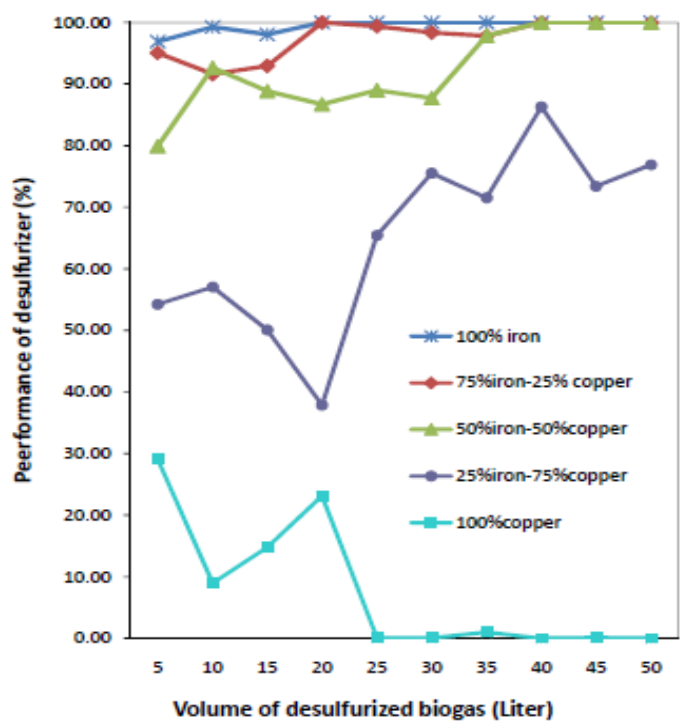

Fig. 4. Performance of copper chips as desulfurizer increase with addition of iron $(\mathrm{Fe})$ chips. Galvanic coupling occur and make more reactive to $\mathrm{H}_{2} \mathrm{~S}$.

The mixture of $\mathrm{Cu}+\mathrm{Fe}$ is obtained with addition of iron. If this mixture is immersed in electrolyte of salt water, this condition will create galvanic coupling. Iron $(\mathrm{Fe})$ will release the ion $\mathrm{Fe}^{2+}$ as can be explained in Fig. 5. The ion $\mathrm{Fe}^{2+}$ is reactive to $\mathrm{H}_{2} \mathrm{~S}$ [10] as can be explain in the reaction in the Fig.5. This reaction will eliminate the $\mathrm{H}_{2} \mathrm{~S}$ impurity in the biogas.

If the iron contents is increased to become $50 \% \mathrm{Fe}$ and similarly happen with $75 \% \mathrm{Fe}$, the reactivity of desulfurizer increase drastically and approaching value of $100 \% \mathrm{Fe}$. There are two reaction of desulfurization to occur i.e. reaction from $\mathrm{Fe}^{2+}$ (Eq. 2) and reaction from iron oxide $\left(\mathrm{Fe}(\mathrm{OH})_{3}\right.$ ) with $\mathrm{H}_{2} \mathrm{~S}$. This iron oxide is very reactive to $\mathrm{H}_{2} \mathrm{~S}$ [6], [7] as reaction in the Eq. 3 bellow: 


$$
\mathrm{Fe}^{2+}+\mathrm{H}_{2} \mathrm{~S} \leftrightarrow \mathrm{FeS} \downarrow+2 \mathrm{H}^{+}
$$

$$
2 \mathrm{Fe}(\mathrm{OH})_{3}+3 \mathrm{H}_{2} \mathrm{~S} \rightarrow \mathrm{Fe}_{2} \mathrm{~S}_{3}+6 \mathrm{H}_{2} \mathrm{O}
$$

The Copper is not reactive to $\mathrm{H}_{2} \mathrm{~S}$. The galvanic coupling between $\mathrm{Cu}$ and $\mathrm{Fe}$ resulting in more rapid reaction between $\mathrm{Fe}$ and $\mathrm{H}_{2} \mathrm{~S}$. The sediment of sulfur as a proof that reaction $\mathrm{Fe}$ and $\mathrm{H}_{2} \mathrm{~S}$ to occur in the mixture can be detected by using laser-induced breakdown spectroscopy (LIBS) as can be seen in Fig. 6.

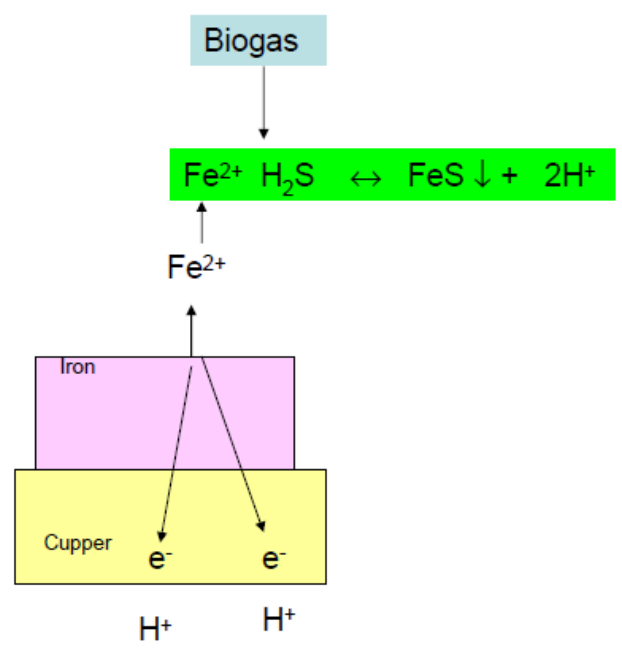

Fig. 5. Schematic reaction of ion $\mathrm{Fe}^{2+}$ with $\mathrm{H}_{2} \mathrm{~S}$ from biogas. The ion of $\mathrm{Fe}^{2+}$ release from surface of iron due to galvanic coupling with copper.

A different phenomenon is observed in this research (mixture of $\mathrm{Cu}+\mathrm{Fe}$ ) if compared with our previous research by using mixture of $\mathrm{Al}+\mathrm{Fe}$ [9]. In this research only $\mathrm{Fe}$ that reacted with $\mathrm{H}_{2} \mathrm{~S}$ according reaction in the Eq. 2 and Eq. 3. And there is no reaction between $\mathrm{Cu}$ and $\mathrm{H}_{2} \mathrm{~S}$. This is meaning that addition of iron chips $(\mathrm{Fe})$ is necessary for the regeneration of desulfurizer. In the case of mixture of $\mathrm{Al}+$ $\mathrm{Fe}$ [9] both metal ( $\mathrm{Al}$ and $\mathrm{Fe}$ ) react with $\mathrm{H}_{2} \mathrm{~S}$ according reaction in Eq.4 bellow [9] and the other reaction is between Iron with $\mathrm{H}_{2} \mathrm{~S}$ as in the Eq.3.

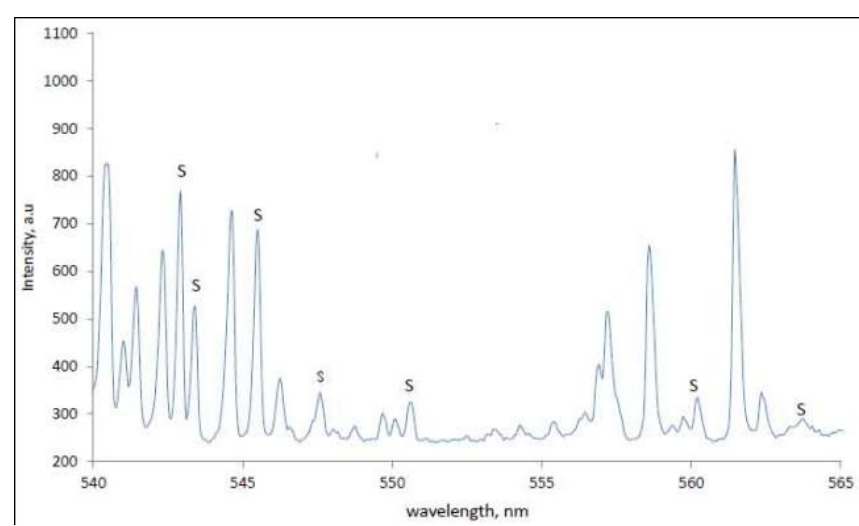

Fig. 6. Sediment of Sulfur (S) as a result of desulfurization was detected in the mixture of $25 \% \mathrm{Cu}+75 \% \mathrm{Fe}$. Laser-induced breakdown spectroscopy (LIBS) was utilized for this purpose.

$$
2 \mathrm{Al}^{3+}+3 \mathrm{H}_{2} \mathrm{~S} \leftrightarrow \mathrm{Al}_{2} \mathrm{~S}_{3} \downarrow+6 \mathrm{H}^{+}
$$

The waste of copper alloy chips is suitable to be utilized as desulfurizer. The copper alloy chips should be mixed with iron chips in order the galvanic coupling to occur and release ion $\mathrm{Fe}^{2+}$. The ion $\mathrm{Fe}^{2+}$ is reactive to $\mathrm{H}_{2} \mathrm{~S}$. The galvanic coupling between copper and iron can be done by mixing the copper and iron continued by put in the salt water as electrolyte.

\section{ACKNOWLEDGMENTS}

The authors wish to thanks the Ministry of research Technology and Higher Education (Ristek-Dikti) The Republic of Indonesia for financial support under Scheme Science and Technologi for Society (Iptek Bagi Masyarakat/IbM) for the years 2016 granted through Udayana University, Jimbaran, Bali, Indonesia.

\section{REFERENCES}

[1] W. E. Kleinjan, C. L. Marcelis, A. D. Keizer, A. J. H. Janssen, and M A. C. Stuart, "Foam formation in a biotechnological process for the removal of hydrogen sulfide from gas streams," Colloids and Surface A: Physicochemical Engineering Aspects, vol. 275, no. 1-3, pp. 36-44, 2006.

[2] E. Y. Lee, N. Y. Lee, K. S. Cho, and H. W. Ryu, "Removal of hydrogen sulfide by sulfate-resistant," Journal of Bioscience and Bioengineering, vol. 101 , no. 4, pp. 309-314, 2006

[3] P. Cosoli, M. Ferrone, S. Pricl, and M. Fermeglia, "Hydrogen sulphide removal from biogas by zeolite adsorption," Chemical Engineering Journal, vol. 145, no. 1, pp.86-92, 2008.

[4] W. Yuan and T. J. Bandosa, "Removal of hydrogen sulfide from biogas on sludge-derived adsorbents," Fuel, vol. 86, no. 17-18, pp. 2736-2746, 2007.

[5] M. Seredych, C. Strydom, and T. J. Bandosz, "Effect of fly ash addition on the removal of hydrogen sulfide from biogas and air on sewage sludge-based composites adsorbents," Waste Management, vol. 28, no. 10, pp. 1983-1992, 2007.

[6] T. G. T. Nindhia, I. M. Sucipta, I. W. Surata, I. K. A. Atmika, D. N. K. P. Negara, and K. M. T. Negara, "Processing of steel chips waste for regenerative type of biogas desulfurizer," International Journal Of Renewable Energy Research, vol. 3, no. 1, pp. 84-87, 2013.

[7] T. G. T. Nindhia, I W. Surata, I. K. A. Atmika, D. N. K. P. Negara, and A. Wardana, "Method on conversion of gasoline to biogas fueled single cylinder of four stroke engine of electric generator," International Journal of Environmental Science and Development, vol. 4, no. 3, pp. 300-303, 2013.

[8] M. G. Fontana, Corrosion Engineering, McGraw-Hill Book Company, 1989.

[9] T. G. T. Nindhia, I. W. Surata, I. K. A. Atmika, D. N. K. P. Negara, and G. P. A. L. Putra, "Biogas desulfurizer made from waste of aluminium chips," International Journal of Materials, Mechanics and Manufacturing, vol. 2, no. 3, pp. 219-222, 2014.

[10] Vogel, Text Book of Macro and Semi Micro Qualitative Inorganic Analysis, Longman Group Limited, London, 1979.

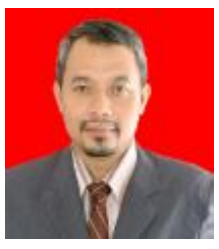

Tjokorda Gde Tirta Nindhia received the doctor degree in mechanical engineering from Gadjah Mada University (UGM) Yogyakarta, Indonesia in August 2003, with major field of study was material engineering.

He participated in various international research collaborations such as with Muroran Institute of Technology Japan (2004), Toyohashi University of Technology Japan (2006), Leoben Mining University Austria (2008-2009), Technical University of Vienna Austria (2010) and recently with Institute Chemical technology of Prague Czech Republic (2012-now). His current job is as full professor in the field of material engineering at the Department of Mechanical Engineering, Engineering Faculty, Udayana University, Jimbaran, Bali, Indonesia. His research interest covers subjects such as, biomaterial, waste recycle, failure analyses, ceramic, metallurgy, composite, renewable energy, and environmental friendly manufacturing.

I. Wayan Surata received the doctor degree in the field of ergonomic from Udayana University in 2011. His research interest very much related in process of manufacture. His current job is researcher and lecturer at

\section{CONCLUSION}


Department of Mechanical Engineering, Engineering Faculty, Udayana University, Jimbaran, Bali, Indonesia.

Tjokorda Sari Nindhia got the doctor of veterinary medicine (DVM) at Faculty of Veterinary Medicine Udayana University, Bali, Indonesia since 1999. Finishing her master degree at biotechnology and biomolecular at postgraduate studies Udayana University in 2010.

Dewa Ngakan Ketut Putra Negara received the M.Sc from University of Bradford, UK in 2001 in manufacturing systems engineering and management. His current job is researcher and lecturer at thr Department of Mechanical Engineering, Engineering Faculty, Udayana University, Jimbaran, Bali, Indonesia.

Mega Diantoro was an undergraduate student, the Department of Mechanical Engineering, Engineering Faculty, Udayana University Jimbaran, Bali, Indonesia. 